Видимо, ужасы Второй мировой войны, глумление над личностью вынудили международное сообшество создать этот документ.

Учреждение в России института Уполномоченного по правам человека - это еще один шаг, который вводит Россию в подлинно демократическое международное сообщество. Россия вместе с другими странами сегодня провозглашает, что более высокой ценности, чем человек, его права и достоинства в мире не существует.

Интервью в конце июля 1998 г. взял В. П. Пархитько.

\title{
ПРИНЦИП ДЕМОКРАТИИ В МЕЖДУНАРОДНОМ ПРАВЕ
}

\section{И.И. Л у к а ш у $\mathrm{k}^{*}$}

История свидетельствует о неразрьвной связи демократии и цивилизации. Цивилизованное общество мыслимо лишь как демократическое. Демократическим может быть лишь цивилизованное общество. Собственно говоря, демократия - необходимый элемент цивилизации.

Сегодня эта связь регулярно подчеркивается государственными деятелями. Выступая на заседании Совета Безопасности ООН в 1992 г., Президент России Б.Н. Ельцин говорил о том, что "важнейшим приобретением человеческой цивилизации стала демократия". 1

Оба понятия историчны. Кахдой эпохе присущ свой уровень цивилизации и демократии. Великие революции совершались под знаменем демократии. Декларация независимости Соединенньгх Штатов Америки 1776 г. провозгласила неотчуждаемость основньх прав человека, для обеспечения которых создакося правительства, заимствуюшие свою справедливую власть из согласия управляемьг. Народ вправе создать свое независимое государство.

Французская революция конца XVIII в. провозгласила Декларацию прав человека и грахданина 1791 г., содержание которой отражено в праве государств и в международном праве. Конституционное право революционной Франции содержало

- Профессор, доктор юридических наук, член Комиссии международного права $\mathrm{OOH}$. 
отказ от ведения завоевательньх войн и от обращения своих вооруженных сил против свободы какого-либо народа. Утверждался также принцип невмешательства в дела других государств. Ряд демократических положений современного международного права были сформулированы в известной декларации аббата Грегуара.

Октябрьская революция в России в Декрете о мире 1917 г. сформулировала концепцию справедливого, демократического мира. Захватнические войны объявлялись величайшим преступлением перед человечеством. Не должно быть места насильственному присоединению чужих народностей и захвату земель. Провозглашалось право всякой народности решать свою судьбу путем добровольно вырахенного согласия.

Мир должен быть справедливым, основанным на "равно справедливьх для всех без изъятия народностей условиях". Мир должен быть демократическим как в международном, так и в национальном плане. Он устанавливается с участием всех без изъятия наций. Его условия подлежат окончательному утверждению "полномочными собраниями народньх представителей всех стран".

После провозглашения указанньх идей государства уходили от них в своей реальной политике. И тем не менее идеи постепенно утверждались в международной и национальной жизни, демонстрируя свое соответствие закономерностям исторического развития. Демократия внутри государств и в их взаимоотношениях необходима как для благополучия всех стран, так и для зыживания человечества.

Несмотря на прогресс достигнутый в области демократизации национальнй и мехдународной жизни, было бы неправильно недооценивать сложность проблемы. В канун XXI века лишь треть гсударств можно, не без оговорок, отнести к категории демократических. В ежегодном докладе ООН "Развитие человечества" (1993 г.) говорилось, что вопреки развитию демократии во всем мире, 90\% населения планеты не имеет возможности контролировать действие институтов власти, затрагивающих их судьбы.

Следует также учитывать, что национальная демократия не является полной гарантией демократии мехдународной. Достаточно обратить внимание на то, что и в наше время демократические государства порою позволяют себе применение силы и угрозы силой в мехдународньх отношениях. Демократия национальная не находит должного отражения во внешней политике государства. Этот факт констатируют как государственные деятели, так и ученџе. 
В этой области, впрочем как и в области международного права в целом, политическое мышление отстает от требований жизни. Это обстоятельство нередко констатируется и руководителями внешней политики. Ссылаясь на него, Министр иностранных дел России Е. Примаков пишет: "Прекращение блоковой конфронтации при всем своем историческом значении автоматически не привело к торжеству демократических принципов в международных отношениях."2

Утверждение принципа демократии вносит существенные перемены в характер международного права, в содержание его основньг принципов, существенно расширяет права международного сообшества в целом. В Венской декларации о правах человека 1994 г. говорится: "Международному сообшеству следует способствовать укреплению и поощрению демократии ..." (раздел I/8).

Несмотря на все трудности, связанные с утверждением принципа демократии, прогресс в этой области ощутим. Демократические принципы никогда еще не были столь значимы во внутренней и международной жизни государств, как ньне.

Принцип демократии находит отражение во все большем числе многосторонних и двусторонних международньх актов. Oсобое место, естественно, принадлежит Уставу ООН. Устав закрепил единство мира, сотрудничества и демократии. Содержание воплощенной в Уставе идеи демократии было раскрыто Б. Бутросом-Гали.

Он показал, что демократия в семье наций - один из неотьемлемых принципов системы международных отношений, предусмотренной Уставом ООН. При этом обоснованно указывал на два аспекта принципа демократии: "демократия в семье наций" и "демократия в рамках государств". Сочетание обоих аспектов - характерная черта не только самого принципа, но и современного международного права. При этом оба аспекта взаимосвязаны, образуют органическое единство принципа. Рост значения демократии в обоих аспектах привлекает к ней внимание исследователей. ${ }^{3}$

1. ПРИНЦИП ДЕМОКРАТИИ В КОМПЛЕКСЕ ОСНОВНЫХ ПРИНЦИПОВ МЕЖДУНАРОДНОГО ПРАВА

Связь демократии и мира издавна отмечается выдающимися мыслителями. И. Кант в своем труде "К вечному миру" (1795 г.) писал о том, что война несовместима с правами человека. Демократическое правление, не будучи полной гарантией, тем не менее является одним из необходимьх условий предотвращения нарушений мира. Одновременно право рассматривалось как единственное средство, способное обеспечить мир внутри стра- 
ны и в международных отношениях. ${ }^{4}$ Аналогичные мысли в то же время излагал русский мыслитель В.М. Малиновский в своем труде "Рассуждения о мире и войне" (1803 г.)

Несмотря на очевидность приведенньх мыслей, потребовалось много времени, прежде чем они стали находить признание в реальной политике и международном праве. Важнейший этап в этом плане был ознаменован принятием Устава ООН.

Свое понимание демократии применительно к ООН Б. Бутрос-Гали изложил следуюшим образом: присущая системе международных отношений, предусмотренной Уставом ООН, демократия является принципом. ${ }^{5}$ Он требует предоставления всем государствам, большим и мальм, всех возможностей высказать свое мнение и принимать участие в деятельности ООН. Он означает, что все органы ООН должны получить и реализовать возможность в полной мере играть свою надлежащую роль. Демократия означает также уважение демократических принципов в процессах взаимодействия вне ООН. ${ }^{6}$

Таким образом, Устав ООН - основополагающий акт для понимания содержания принципа демократии. Главная цель $\mathrm{OOH}$ - избавить грядушие поколения от бедствий войны увязана с целью утвердить веру в основные права человека, в равенство прав больших и малых наций. В этом видится связь международного мира с демократией не только на мировой арене, но и внутри государств. Сказанное подтверждается и целью "содействовать социальному прогрессу и улучшению условий жизни при большей свободе." Устав определил как цели, так и принципы демократического миропорядка.

Важная особенность Устава состоит в том, что он отходит от традиционного политического мьшшения, которое видело в государствах единственную реальность в международной жизни. Устав стал на защиту прав человека и народов. Они становятся носителями интересов, которые должны обеспечиваться государствами и международным правом в первоочередном порядке. Такое положение ограничило правовыми рамками свободу действий государства в международных отношениях и внутри страны в пользу прав и интересов человека и народа.

Устав предусматривает, что прием в члсны ООН открыт для всех "миролюбивых государств, которые примут на себя содержащиеся в настоящем Уставе обязательства и которые, по суждению Организации, могут и желают эти обязательства выполнять" (ч. 1 ст. 4). Представляется, что сегодня по суждению Организации этим требованиям могут отвечать только государства, достигшие определенного стандарта демократии. Только 
они способны выполнять должньм образом обязательства по Уставу.

Подтверждение тому находим в ряде документов. Всеобшая декларация прав человека 1948 г. установила, что "воля народа будет основой власти правительства" (ст. 21.3). ${ }^{7}$

Генеральная Ассамблея ООН определила, что "любое государство, официальная политика или практика которого основывается на расовой дискриминации такого рода, как апартеид, нарушает цели и принципы Устава Организации Объединенных Наџий и, следовательно, для него не должно быть места в Организащии Объединенньх Наций."

Ныне Ассамблея ставит новые задачи: "Изучить пути и механизм, при помощи которых система Объединенных Наций могла бы поддерживать усилия правительств по развитию и упрочению новой демократии или ее восстановлению". 9 Это свидетельствует о становлении новой функщии ООН, имеющей важное значение для утверждения демократии в государствах.

Сооветствующие положения резолюџий Генеральной Ассамблеи, зачастую в еще более развернутом виде, нашли отрахение в документах других международньг организаций и движений. ${ }^{10}$ В одном из документов Комиссии Европейских сообществ подчеркивается: "Уважение к правам человека является одним из главньгх условий членства в Европейском Союзе”.11

Принцип демократии находит отражение и развитие в двусторонних и групповых договорах и иных международньх актах. В Российско-шведской декларации на высшем уровне 1993 г. говорится, что участники "разделяют уважение к принципам демократия, верховенства права, прав и свобод человека, социальной справедливости" 12

Договоры указывают в качестве общей цели создание демократического строя. ${ }^{13}$ В них говорится об “обеспечении устойчивого демократического развития государств. ${ }^{14}$

В Хартии о российско-американском партнерстве и дружбе 1992 г. президенты заявили о своей решимости строго придерживатъся демократических принципов и практики, включая верховенство прав и уважение прав человека. Участники выразили намерение тесно взаимодействовать на мехдународной арене в интересах продвижения и защиты общих демократических ценностей. ${ }^{15}$

О конкретньх направлениях сотрудничества в области демократии можно судить по Договору между Россией и Францией 1992 г. Стороны будут способствовать "преобразованию Европы в общее правовое и демократическое пространство" (ст. 6).

Основные направления сотрудничества "в области демокра- 
тических институтов и правового государства" определены следуюшим образом: а) конституционные, законодательные и административные нормы; б) конституционный надзор и контроль за исполнением законов; в) гражданские свободы, права человека, права национальньх меньшинств; избирательные системы (ст. 10). ${ }^{16}$ Из этого видно, что сотрудничество в области демократических институтов затрагивает вопросы, которые еще вчера считались чисто внутренними.

В литературе получил широкое распространение тезис о том, что только демократическое государство является сегодня легитимным и может рассчитывать на международное признание. ${ }^{17}$

Подобная позиция встречает критическое отношение со стороны других авторов. О. Шахтер видит вызов юридическому понятию государства "в политической и моральной позиции, согласно которой индивидуальные права и демократическое правление следует считать условием признания государственности."18

Речь, однако идет прежде всего не о признании государственности, а о качествах, необходимых для полноправного участия в международных органах и организациях. Сегодня, пожалуй, лишь крайне антидемократическне режимы являются незаконными с точки зрения международного права. ${ }^{19}$

Таким образом, современное международное право обязывает государства обеспечить определенный уровень демократии в их политической системе. Сложнее обстоит дело с последствиями невыполнения этой обязанности. Соответствуюшие нормы находятся в процессе становления. Тем не менее уже сегодня наиболее грубые нарушения прав человека становятся основанием для применения санкций такой универсальной организацией, как ООН.

Значительно дальше идут некоторые региональные организации, объявляя достижение определенного уровня демократии необходимым условием членства. Снижение этого уровня ведет К приостановлению или прекращению членства. В 1983 г. Парламентская Ассамблея Совета Европы приняла резолюцию, в которой дальнейшее пребывание Турции в Совете было поставлено в зависимость от соответствия нового турецкого законодательства Уставу Совета и Европейской конвенции о зашите прав человека. ${ }^{20}$ Европейский Союз по тем же основаниям не раз отказывал Турции в приеме в состав членов.

В 1997 г. Европейский Союз применил санкции в отношении Белоруссии на том основании, что ее пересмотренная конституция не соответствует международным стандартам демократии. В частности предусматривалось, что "ни ЕС, ни европейские госу- 
дарства не будут заключать с Белоруссией каких-лиоо соглашений...

Международные организации и отдельные государства вправе учитывать степень соответствия государства демократическим стандартам при решения вопроса о признании государства или правительства. В 1992 г. Европейское Сообщество выдвинуло в качестве условий признания Республики Грузия - права человека, законность и демократию. Грузия приняла эти условия.

Близка к этому практика отказа в признании полномочий представителей антидемократического режима. Такая мера применялась ООН в отношении расистских режимов. В течение нескольких лет после событий 1956 г. в Венгрии ООН отказывалась признавать полномочия представителей ее правительства.

Утверждение в практике концепции демократической легитимации вызывает определенные опасения. Указывают на возможность злоупотребления ею. селективного подхода и др. ${ }^{21}$ Одновременно многие авторы обоснованно отмечают, что отмеченная концепция не означает ни ликвидации, ни ограничения суверенитета государств. Речь идет о новьг функциях государства, международного права и суверенитета. ${ }^{22}$

Нет сомнения в том, что концепция демократической легитимации открывает значительные возможности для злоупотреблений. Но то же самое можно сказать и о многих других институтах международного права. Ее эффективность будет зависеть от уровня цивилизованности международньх отношений, от упрочения позиций демократии, законности и морали. Несмотря на все трудности, утверждение этой концепции представляется закономерным шагом на пути прогрессивного развития международного права.

Положения Устава получили развитие в Декларашии о принципах международного права, касающихся дружественньх отношений и сотрудничества между государствами в соответствии с Уставом ООН, 1970 г. Свое выражение идея демократии нашла, прежде всего, в том, что принципы международного права гарантировали основные права государств. Их задача обеспечить демократический мировой порядок.

На первом месте находится право государства на мир и безопасность. Поставлены вне закона угроза силой или ее применение. Международное право тем самым сделало исторический шаг, заменяя силу правом. Все это явилось важнейшей предпосылкой для утверждения демократии.

Принцип неприменения силы установил коллективную ответственность государств в отношении поддержания мира и без- 
опасности. Это явилось необходимой гарантией реальности принципа демократии.

Международное право уделяет растущее внимание предотвращению конфликтов. Концепция должна быть распространена и на вооруженные конфликты немеждународного характера.

В новых условиях встал вопрос о создании коллективной демократической безопасности. ${ }^{23}$ Первые шаги по продвижению этой идеи в практику государств сделаны. Принявшие Парижскую хартию для новой Европы 1990 г. государства признали для себя демократию как единственно приемлемую систему правления и заявили: "Наши государства будут сотрудничать и оказывать друг другу поддержку с целью сделать демократические завоевания необратимыми".

Принцип сувереннопо равенства государств - следующий принцип большого значения для понимания содержания принципа демократии. Независимо от каких бы то ни было различий все государства являются равно суверенными Они обладают одинаковыми суверенными правами и являются равноправными членами международного сообшества. Каждое государство имеет право свободно выбирать и развивать свою политическую, социальную, экономическую и культурную систему. Суверенное равенство предполагает уважение прав и законных интересов другнх государств, а также добросовестное выполнение обязательств по международному праву.

Обеспечение суверенных прав государства и верховенства права - функщия демократических принципов. Важным ее аспектом является обеспечение реального участия государств в принятии решений по вопросам, представляющим общий интеpec. Демократия означает право на участие в принятии решений.

В прошлом в международной жизни господствовали могучие державы. Они целиком контролировали процесс принятия решений, создание норм международного права. Существовала так называемая "свобода договоров", дававшая возможность могучим державам заключать договоры по любым вопросам, включая и те, что затрагивали права и законные интересы третьих государств. Они же решали вопрос о приглашении $\mathrm{k}$ участию в договоре других государств.

В соответствии с принципом суверенного равенства каждого государство вправе участвовать в решении общих проблем.24 Приоритетньм правом на участие пользуется государство, интересы которого непосредственно затрагиваются. Признание этого положения проходило с трудом. На Венской конференции по праву договоров (1968-1969 гг.) ряд государств продолжали отстаивать “свободу договоров", другие настаивали на закрепле- 
нии права на участие в договорах. В результате ни то, ни друтое не было закреплено Конвенцией. ${ }^{25}$ Право на участие не нашло должного отражения и в Декларации о принципах международного права.

Несмотря на все это, право на участие утверждается в международно-правовой практике. Сегодня все принимаемые в системе ООН конвенции основаны на принципе всеучастия. Он закрепляется и в уставах международньх организаций. ООН открыта для членства всех миролюбивых государств. Принцип всеучастия закреплен, например, Уставом Международного союза электросвязи (ст. 2). Что же касается формирования правил, касаюшихся участия государств в ограниченньх договорах и органах, то оно происходит довольно медленно.

В сочтветствии с принципом демократии решения по общим проблемам и при создании норм общего мехдународного права принимаются международным сообшеством государств в целом. Это положение закреплено ст. 53 Венской конвенции о праве договоров. Оно требует не единогласия всех государств, а согласия достаточно представительного большинства.

Широкое распространение получило принятие решений консенсусом. Однако этот метод имеет и свои отрицательные моменты, давая возможность меньшинству блокировать решения большинства. ${ }^{26}$ Еще предстоит решить сложную проблему учета интересов и воли меньшинства при решении общих проблем.

Принциты защищают суверенитет государства не только в отношении внешней, но и внутренней сферы. Запрещается применять и поощрять применение экономических политических мер или мер любого иного характера с целью добиться подчинения себе другого государства.

Содержание принципа суверенного равенства не может быть выяснено без учета требований принщипа демократии. Государства равно суверенны в своих демократических правах и обязанностях, в условиях демократического правопорядка. Вьходящее за эти рамки государство не может рассчитыва־ ъ на равноправное отношение к нему.

Государство суверенно в выборе своей внутренней системы. Однако свобода выбора осуществляется в пределах установленньх демократических стандартов. Главные из них были определены Всеобщей декларацией прав человека: а) кахдый человек должен обладать всеми основными правами и свободами; б) каждый человек имеет право принимать участие в управлении своей страной; в) воля народа должна быть основой власти правительства. Эта воля находит выражение в регулярных демо- 
кратических выборах; г) долхно быть обеспечено верховенство права.

Принщи сотрудничества обязывает государства сотрудничать друг с другом, независимо от существующих между ними различий, в целях поддержания мира и безопасности, содействия международной экономической стабильности и прогрессу, общему благосостоянию народов. Однако, если существующие различия означают отход от принятьх стандартов демократии, то они ограничивают действие принципа сотрудничества.

Обязанность сотрудничать на демократическэй основе во имя общих и особых интересов государств открывает новые возможности в развитии содержания принципа демократии. Правда, пока реальность принципа сотрудничества оставляет желать лучшего.

Принцш добросовестности выполнения обязательств по международному праву - один из важнейших элементов демократии. Без надежного международного правопорядка не может быть и демократии. При этом все большее значение будет приобретать такая его составная часть, как принцип добросовестности. ${ }^{27}$

В резолюции Генеральной Ассамблеи ООН "Упрочение законности" особо подчеркивается значение верховенства права "как существенного фактора в защите прав человека". Более того, в резллющии идет речь "о помощи государствам в решении задачи создания и упрочения адекватньх национальньх структур, которые оказывают прямое влияние на всеобщее уважение прав человека и поддержание правопорядка."28

Как известно современный принцип Pacta sunt servanda на первое место ставит обязательства, вытекаюшие из Устава ООН и основных принципов международного права. Только на соответствующие им обязательства указанный принцип распространяет свое действие. Как уже отмечалось, Устав ООН и основные принципы закрепляют главное содержание принципа демократии. Отступление от этих принципов ведет к недействительности договоров.

Принцип невмешательства претерпевает сушественные изменения. Меняется само понятие внутренних дел, лежащее в фундаменте принципа. Главная роль в этом принадлежит принципу демократии. Перестают быть исключительно внутренним делом такие коренные вопросы жизни государства, как права человека, демократия, верховенство права.

Основная причина перемен была указана во Всеобщей декларации прав человека. всеобщее признание неотьемлемьх прав человека является "основой свободы, справедливости и всеобщего мира". Это положение получило развитие в других между- 
народных актах. Согласно Хельсинкскому документу 1992 г. соответствуюшие вопросы представляют непосредственный законный интерес для всех государств и не являются исключительно внутренним делом какого-то одного государства. ${ }^{29}$ Международный Суд определил, что в международном праве нет препятствий тому, чтобы государство брало на себя обязательства в отношении таких вопросов внутренней политики, как проведение свободных выборов. ${ }^{30}$

Таким образом, вопросы, касающиеся прав человека, демокјатии и верховенства права, ныне носят международный характер и не относятся к числу исключительно внутренних дел государства. Уважение этих ценностей - одна из основ мирного международного порядка. ${ }^{31}$ В Хельсинкском документе 1992 г. это положение расширяется и усиливается: "Защита прав человека, основньх свобод и содействие их осуществлению, а также укрепление демократических институтов остаются жизненно важной основой нашей всеобъемлющей безопасности."

Принцип невм эшательства запрещает любое принуждение, направленное на то, чтобы подчинить своим собственным интересам осуществление другим государством прав, присущих его суверенитету. Это положение не распространяется на меры воздействия сообщества в целях содействия утверждению демократии.

Растет число и разнообразие средств международного воздействия на государство, нарушающее права человека. Создактся международные институты, предусматриваюшие возможность прямого обращения к ним индивида. Знаменательно, что эти институты находят признание в новейших конституциях. ${ }^{32}$

Особого внимания заслуживает гуманитарная интервенция, понимаемая как действия международного сообщества, нацеленные на прекращение массового нарушения прав человека в определенном государстве. ${ }^{33}$ Отмечу, что законность гуманитарной интервенции начинает находить признание в российской доктрине в отличие от ее полного неприятия в период существования СССР. ${ }^{34}$

Опьт свидетельствует, что односторонние действия государства, особенно с применением вооруженной силы, предпринимаемые под предлогом гуманитарной и'нтервенции, редко дают позитивный результат. Они осуждаются международным спобществом. Так, интервенция США в Гренаде и Панаме была осуждена хак ООН, так и ОАГ. ${ }^{35}$ Напомню, что Международный Суд отказался обсуждать возможность образования новой нормы, "создающей право интервенции одного государства про- 
тив другого на том основании, что последнее избрало определенную идеологическую или политическую систему. ${ }^{36}$

Что же касается права ООН и региональных организаций на гуманитарную интервенцию в рамках их уставов и международного права, то оно получило признание. Особенно далеко идущие меры могут предприниматъся Советом Безопасности ООН, когда ситуация по его мнению представляет угрозу миру и безопасносTh.

Еще в 1960 г. Совет применил санкщии в отношении Родезии и Южной Африки в целях прекращения систематического нарушения прав человека. Эта практика продолжалась и в последующие годы. Учитывая массовые репрессии Ирака в отношении собственньх граждан, включая грахдан курдского происхождения, Совет в апреле 1991 г. принял резолюция 688, призвавшую Ирак прекратить репрессии и открыть доступ гуманитарной помощи для пострадавших. ${ }^{37}$ Немало интересных моментов в этом плане содержат и резолюции Совета в отношении событий на территории бывшей Югославии и в ряде других случаев.

Свою роль играет и Генератьная Ассамблея ООН. После того, как Совет Безопасности оказался не в состоянии принять решение по Гаити, Ассамблея в 1991 г. приняла резолюцию 46/7, осудившую переворот в Гаити и потребовавшую немедленно восстановить законное правительство. Ассамблея поддержала резолюцию ОАГ о Гаити и призвала государства-члены ООН принять меры в поддержку этой резолюции.

Получила распространение практика наблюдения международньх организаций за проведением выборов в стране $(\mathrm{OOH}$, ОБСЕ, ОАГ). Б. Бутрос-Гали сообщил, что к 1995 г. ООН оказала содействие примерно 45 странам в проведенин свободньх и беспристрастньх выборов, а также "в строительстве и укреплении демократии". 38

Принятое Генеральной Ассамблеей в 1992 г. положение о миссиях наблюдателей подтверждает, что их деятельность нельзя рассматривать как гуманитарную интервенцию. ${ }^{39}$ Но порою их полномочия могут быть весьма широки. Так, в Кампучии миссия участвовала в создании условий для свободных выборов и в установлении демократической формы правления на основе Парихских соглашений о Камбодже 1991 г. $^{40}$

Принцип невмешательства обязывает другие государства воздерживатъся от оказания помощи деятельности, направленной на насильственное свержение режима другого государства, т.е. антидемократической деятельности. Помощь правительству в сохранении демократии правомерна.. ${ }^{41}$ Принцип демократии за- 
прещает оказание помощи правительству, несущему ответственность за массовые нарушения прав человека в стране.

2. ПРИНЦИП РАВНОПРАВИЯ И САМООПРЕДЕЛЕНИЯ НАРОДОВ

Этот принцип занимает особое положение среди принципов международного права. Последние представляют собой хартию основных прав и обязанностей государств. Принцип самоопределения посвящен правам иного образования, а именно - народа, нации, а также соответствуюшим обязанностям государств. Пакты о правах человека закрепили связь права народа на самоопределение с правами человека (статьи 1).

В результате в международном праве закреплены права тех, кто не является субъектом международного права, а на государства возложена обязанность уважать и обеспечивать эти права. Одним из факторов, вызвавших к жизни подобное положение, явилась демократизация международного права.

Проблема самоопределения народов, наций всегда была одной из сложньх правовьх проблем. Национально-освободительные движения сыграли важную роль в создании независимых государств в Европе, Америке, Азии и Африке и тем самым в формировании демократической международной системы.

Вместе с тем многовековой опыт говорит о том, что национальный эгоизм принес бесчисленные беды народам. И сегодня он служит причиной многих кровопролитий, создает угрозу миру и правам человека. Уменьшение опасности межтосударственных войн, а отчасти и демократизация международньх отношений, содействовали созданию условий, при которьх во многих странах вспыхнули вооруженные конфликты на национальной, этнической, религиозной почве.

Недостаточная определенность принципа самоопределения и многочисленные случаи злоупотребления им со стороны деструктивных националистических сил привели к снижению авторитета этого принципа. ${ }^{42}$

Принцип самоопределения, как и иные приншипы, нельзя понимать как нечто абсолютное. Декларация о принципах международного права 1970 г. подчеркивает, что при толковании и применении принципы являются взаимосвязанньми и кахдый должен рассматриваться в контексте всех других принципов.

Особо подчеркивается связь принципа самоопределения с принципом территориальной целостности. Ничто в содержании первого принципа "не долхно толковаться как санкционирующее или поощряющее любые действия, которые вели бы $\mathbf{k}$ расчленению или к частичному или полному нарушению территориальной целостности или политического единства суверен- 
ных и независимых государств, действуюших с соблюденисм принципа равноправия и самоопределения народов ... и, вследствие этого, имеюших правительства, представляюшие весь народ ..."

Это принципиальное положение подчеркивается и в других международных актах, например, в Заключительном акте СБСЕ 1975 r.

Следовательно, в демократических государствах, отвечающих приведенным выше критериям, право на самоопределение должно осуществляться демократическим путем, в рамках закона. Такое понимание принципа широко признано. Комиссия $\mathrm{OOH}$ по правам человека отрицает, что принцип самоопределения включает право на разрушение демократического государства путем отделения от него.43 Аналогичную позицию занимают и другие международные органы, а также многие авторитеты в области международного права. ${ }^{43}$

Современный мировой порядок мыслим лишь как система организованньх в государства народов. Субъектом права на самоопределение является нменно народ, нация, а не любое социальное образование, например, племя. Касаясь этого вопроса, Б. Бутрос-Гали говорил: "Нация не является племенем: в реальности одно противоположно другому. Нация - это обязательно выход за рамки базовых обществ, это объединение нескольких из них ... Задача нации как раз и заключается в том, чтобы преобразовать примитивные антагонизмы и создать пространство солидарности, благодаря чему она и является очень современным понятием, которое мы находим в Уставе Организации Объединенных Наций".45

Следовательно, правом на самоопределение обладает народ, нация, т.е. достаточно крупная и целостная общность. Этнические, религиозные, языковые меньшинства обладают правом на культурную автономию, на уважение их интересов в рамках демократического государства. ${ }^{46}$

В демократических государствах в рамках законности долхны действовать и политические меньшинства. Порождаемые ими вооруженные конфликты, будь то грахданские войны или революции, влекут за собой массовые нарушения прав человека и создают угрозу миру. Это положение подтверждается и Всеобщей декларацией прав человека. Согласно Декларации охрана прав человека властью закона необходима для того, чтобы человек не был вынужден прибегать в качестве последнего средства к восстанию против тирании и угнетения (п. 3 преамбулы). Эти положения отмечаются и в доктрине. ${ }^{47}$

Таким образом, в международном праве утверждается еще 
один общий прннцип конституционного права - недопустимость насильственного свержения государственной власти, основанной на демократических началах. В обшем это явление закономерно. Принцип демократии предполагает тесное взаимодействие международного и конституционного права.

В доктрине и практике принцип самоопределения зачастую понимается как принцип одноразового действия, как право избрать форму своего государственного существования. Однако из содержания принципа следует, что речь идет о постоянно действующем праве народа свободно определять свой политический статус.

В свете принципа демократии главная цель права на самоопределение состоит в обеспечении народу возможности демократическим путем, без вмешательства извне определять характер общества и государства, основные направления его внутренней и внешней политики.

В соответствии с принципом самоопределения воля народа должна быть основой государственной власти. Во Всеобщей декларации прав человека 1948 г. сказано: "Воля народа должна быть основой власти правительства”. Иньми словами, принцип самоопределения служит утверждению принципа народовластия, который становится общим принципом конституционного и международного права. Конституцией России установлено: "Носителем суверенитета и единственным источником власти в Российской Федерации является ее многонащиональньй народ" (ч. 1 ст. 3 ).

\section{3. ПРИНЦИП УВАЖЕНИЯ ПРАВ ЧЕЛОВЕКА}

Для действия международного принципа демократии внутри страны, пожалуй, самое существенное значение имеет принцип уважения прав человека. Как международное право, так и конституции многих государств дают основания считать, что право на демократическую систему в стране является одним из основньг прав человека. В противном случае права человека превращаются в пустой звук, так как они могут быть обеспечены лишь в условиях демократии. В своей совокупности права человека являются сушностью демократического правления.

Опыт показыпает, что интересы народа далеко на всегда обеспечиваются государством. Свидетельством тому являются многочисленные войны, принесшие неизмеримые бедствия народам. Известно немало случаев, когда отечественное государство наносило благополучию народа самый большой ущерб. Международные отношения были отданы на откуп государствам, а точнее правительствам, интересы которых далеко не всегда совпадали с интересами народов. История поставила задачу 
повернуть мировой порядок и мехдународное право лицом к народу и человеку, поставить на первое место зашиту их прав и интересов. Международное, как и внутреннее право, призвано стать гомоцентричным, ориентированным на человека. Приоритет основных прав человека становится общим принципом международного и конституционного права демократических государств.

Ках христианская и мусульманская, так и другие религии исходят из того, что человечество образует единое сообщество, связанное единьми правилами. Вместе с тем и сегодня религиозные традиции наряду с политическими и иными являются существенными препятствием на пути формирования права единого международного сообщества. ${ }^{48}$

Такому праву необходима единая как для него, так и для конституционного права система ценностей. Международное право становится важным инструментом формирования такой системы. В ее основе лежат такие высшие ценности, как демократия, права человека, верховенство права. Утверждение их ведет к обеспечению внутренней и международное безопасности государства, народа, человека.

Таким образом, происходит определенная деэтатизация международного права. Однако это вовсе не значит, что следует замснить международное право транснациональным, мировьм правом или придать физическим и юридическим лицам статус субъектов.

Природа мехдународного права определяется характером его объекта, то есть регулируемьх отношений. Им является особая разновидность социальных отношений - отношения между суверенными государствами. Управляющая подсистема мировой системы мыслима лишь как состоящая из государств. Благодаря своей суверенной власти они создают нормы международного права, наделякт их юридической силой и обеспечивакт осуществление. Без государства невозможно обеспечить и права человека. Все международные акты о правах человека рассматривают государство как основной инструмент обеспечения этих прав и возлагают на него соответствующие обязанности.

Поэтому задача состоит не в том, чтобы изменить межтосударственный характер международного права, а в том, чтобы поставить его на службу не только государствам, но также народам и человеку. Важную роль в решении проблемы призван сыграть принцип демократин. Он дает возможность установить внешний контроль со стороны международного сообщества за соблюдением прав человека в государстве, а также внутренний контроль со стороны народа, человека. 
Деэтатизация находит выражение в том, что международное право ставит на первое место права народа и человека. Только на такой основе можно создать международный порядок достойный человеческой цивилизации XXI века. Ни государство, ни какая-либо группа или какое-либо лицо не имеют права совершать какие бы то ни было действия, направленные на уничтожение или неправомерное ограничение любьх международно признанных прав и свобод (ст. 5/1 Международного пакта о гражданских и политических правах). Это положение находит подтверждение и в национальньх правовьх системах. ${ }^{49}$

В международном и внутреннем праве демократических государств права человека рассматриваются как высшая моральная и правовая ценность. Они объяляюося неотьемлемыми, принадлежашими человеку от рохдения, а не создаваемыми законами государства. Их обеспечение - первейшая обязанность государства.

Закрепив эти положения. Конституция России поставила обшепризнанные нормы о правах человека на высший уровень в правовой системе страны: "В Российской Федеращии признаются и гарантируются права и свободы человека и гражданина согласно общепризнанньм принципам и нормам международного права и в соответствии с настоящей Конституцией" (ч. 1 ст. 17).

Происходит сближение международного и конституционного права в области зашиты прав человека на базе общих принципов права. Без этого невозможно было бы надежно обеспечить ни права человека, ни демократических международный порядок.

Отмечая противоречия между интересами государства, с одной стороны, и народа, человека, с другой, нельзя не сказать и о том общем, что их объединяет. Как те, так и другие должғы осуществляться в соответствии с целями и принципами Устава ООН. (Ст. 29/3 Всеобщей декларации прав человека).

Это положение призвано гармонизировать осуществление указанных прав. Недопустимо злоупотребление правами человека в ущерб правам народа и государства. Всеобщая декларация подчеркивает, что каждый человек имеет обязанности перед обшеством, в котором только и возможно свободное развитие его личности. Предусмотрена возможность ограничения осуществления прав человека в интересах общественного порядха и общего благосостояния в демократическом обществе (ст. 29). Этому положению уделяют значительное внимание региональные акты. ${ }^{50}$ Принцип демократии требует не противопоставления прав человека и государства, а их гармонизации на демократической основе.

В новых условиях становится особенно актуальным вопрос о соотношении роли государства и мехдународных органов в обес- 
печении прав человека. Основная роль сохраняется за государством. Задача международных органов - воздействовать на государство в нужном направлении, а не подменять его.

Недостаточная эффективность государства в решении как внутренних, так и международных проблем стимулирует тенденцию к делегитимации государственной власти, к падению ее авторитета в общественном мненин. Одновременно наблюдается тенденция к легитимации международньх органов.

Однако последняя тенденция пока не очень ошутима. Объясняется это тем, что международные органы далеко не вполне оправдывают ожидания широких кругов населения, особенно, когда речь идет о политических органах. Причин тому немало. Остановлюсь лишь на одной из них, имеющей прямое отношение к принципу демократии.

Современный механизм принятия решений на международном уровне не вполне отвечает требованиям демократии. Каждое государство имеет один голос как в том случае, когда оно представляет многие миллионы людей, так и в том, когда речь идет о десятках тысяч.

Международные организации являются межправительственными. Парламенты оказывают на их деятельность незначительное влияние, а между тем значение принимаемых решений растет. Вьход видится, прежде всего, в учреждении при ООН парламентской ассамблеи с представительством, пропорџиональном численности населения. Первые шаги в этом направлении делаются на региональном уровне (ОБСЕ, ЕС, СНГ). Показательно, что значение этой проблемы подчеркивалось рядом участников Конгресса по международному публичному праву. ${ }^{51}$

Участие в решении мехдународньх проблем требует высокого профессионализма. Этому требованию не всегда отвечают члены законодательньх органов. Поэтому целесообразно не прямое представительство парламентов и их фракций, а создание особого института представителей, избираемњх первоначально парламентами, а в даљьейшем и всеобщим голосованием.

Принцип уважения прав человека требует существенньх изменений в механизме действия международного права. Вытекаюшие из него обязательства являются обязательствами erga omnes. ${ }^{52}$ Опьт деятельности ООН доказьвает, что в современньх условиях коллективная ответственность государств за обеспечение всеобщего уважения прав человека может стать реальностью.

Существенное значение имеет учреждение Международного уголовного суда и принятие Кодекса преступлений против мира и безопасности человечества. Международное сообщество обязано обеспечить индивидуальную ответственность государствен- 
ных деятелей, инициировавших вооруженные конфликты, виновньх в массовых нарушениях прав человека.

Одним из препятствий на пути утверхдения принципа демократии является отставание политического мышления от требований времени. Подтверждение тому можно обнаружить и в таком акте, как Программа Десятилетия международного права ООН, которая в целом отрахает этатизированную концепшию международного права прошлого. В ней не нашли должного отражения не только проблемы демократии в целом, но и такого ее элемента, как уважение прав человека. Полностью отсутствуют положения о внутригосударственной имплементации норм международного права.

Между тем проблема обеспечения оптимального взаимодействия международного и внутреннего права, прежде всего, конституционного, приобретает особенно выжное значение. Международное и конституционное право долхны опиратъся на общие демократические принципы. Опыт подтверждает большие возможности международного права в области демократизации конституционного права. Иллюстрацией тому могут слухить новые конституции стран Центральной и Восточной Европы, а также других стран. ${ }^{53}$

ЗАКЛЮЧЕНИЕ

Принцип демократии представляет собой одну из основ цивилизованного международного сообщества и соответствующего права. Только на его основе можно обеспечить оптимальное управление системой международньх отношений, необходимый для этого уровень сотрудничества государств и, следовательно, решение стояших перед человечеством проблем. Поэтому демократия - одна из важнейших общечеловеческих ценностей.

Основными элементами содержания принципа демократии являются права человека, демократический механизм принятия решений, верховенство права.

Первоначально принцип демократии действовал как принцип-идея. Он претворялся в жизнь через иные правовые нормы. С принятием Устава ООН интенсифицировалось становление собственного нормативного содержания принципа. Правда, как в наше время, так и в будущем он в значительной мере будет действовать также через иные принципы и нормы, определяя и развивая их содержание.

Характерная черта современного принципа демократии в том, что он распространяет свое действие и на внутригосударственную сферу, затрагивая центральные институты конституционно-правовой системы.

Утверждение принципа демократин оказьпает влияние не только на содержание, но и на механизм действия международ- 
ного права, включая его взаимодействие с внутренним правом государств.

Единство мира требует, чтобы правовые системы государств строились как части единого целого. Они должны быть способны активно взаимодействовать друг с другом и с международной системой в целом.

Принцип демократии требует, чтобы международный и внутренние правопорядки опирались на общие демократические принципы. Только на такой основе можно сегодня обеспечить необходимый уровень взанмодействия государств.

Демократическое и правовое международное сообщество должно состоять из демократических и правовых государств. Поэтому принцип демократии обязывает государства обеспечить соответствие их правовых систем общепринятым стандартам демократии. Принцип предусматривает возможность оказания государству помощи в достижении этой цели.

Полноценным членом международного сообщества способно быть лишь государство, отвечаюшее обшепринятьм стандартам демократии. Нельзя быть членом сообщества, не уважая его устоев. Формируются нормы, регулируюшие меры воздействия на те государства, которые отклоняются от принятых стандартов демократин.

В международном праве утверждается общая система демократических ценностей. Упрочивается его моратьная основа, усиливается влияние на правосознание широких слоев населения.

Демократия открывает немалые возможности для злоупотребления ею. Поэтому ее необходимым дополнением является принцип незлоупотребления правом, который будет постепенно упрочивать свои позиции в международном праве. ${ }^{54}$ Права государства и человека кончаются там, где начинаются права другого человека, государства и международного сообщества в целом.

В рамках некоторьх региональньх объединений формируется система демократической коллективной безопасности. Государства берут на себя обязательство сотрудничать и оказывать друг другу поддержку с целью сделать демократические достижения необратимыми.

Совершенствование механизма реализации прав человека будет происходить главньм образом не по линии передачи функций государства международньм органам, а путем усиления международного воздействия на государства. Поскольку только они способны обеспечить всеобщее уважение прав человека и верховенство права.

С учетом углубляющейся институционализации международных отношений особое значение приобретает демократизация 
международньг организаций, прежде всего, общего характера. Кроме того, будет смягчен исключительно межправительственный характер организаций в результате учреждения органов парламентского характера.

Растет значение позитивной ответственности государств за обеспечение демократии на национальном и интернациональном уровнях. Это требует преодоления догм устаревшего политического мышления, основанного на национальном эгоизме.

Перед межпународным правом жизнь ставит все новые сложные задачи. Растет объем и интенсивность международных связей физических и юридических лиц, углубляется интернационализация национальных обществ. Идет процесс становления международного грахданского общества. Жизнь требует создания нового мирового порядка, о чем постоянно говорят государственные деятели. Такой порядок не может не опираться на демократические принципы.

Формирование и функщионирование нового мирового порядка зависит от существенного повышения уровня интернационального воспитания широких слоев населения, от роста их правовой культуры. Задача исключительно сложная. Поэтому нельзя не приветствовать то обстоятельство, что Программа Десятилетия международного права ООН уделяет столь существенное внимание задаче распространения международно-правовых знаний, изучению и преподаванию мехдународного права.

1 Российская газета, 1992, 3 февраля.

2 Е. Примаков. Международные отношения нахануне XXI века: проблемы и перспективы. - Мехдународная жизнь, 1996, № 10, с. 3.

3 Г. Дмитриева, И. Лухашук. Международный принщип демохратии. Международная жизнь. 1992, № 11-12; J. Crowford: Democracy in International Law. Cambridge. 1996; T. Franck. The Democratic Entitlement. - University of Richmond Law Review, 1994, N. 1.

4 Трахтаты о вечном мире. М.: 1963. С. 152-153, 184.

5 Agenda for Development (1994), p. 134.

6 Доклад Генерального Секретаря на 48-й сессии Генераљной Ассамблеи ООН. - Государство и право, 1995, № 1, С. 13. Об основных направлениях деятельности ООН в области демократии. См. report "An Agenda for Democratization". U.N. 1997.

7 M. Reisman пишет: “Международная система правотворчества продолжает устанавливать критерии для оценки соответствия внутреннего управления международным стандартам демохратии."/M. Reisman. Sovereignty and Human Rights in Contemporary Intemational Law. - AJIL. Vol. 84 (1990), No. 4, p. 868.

8 Резолюция Генеральной Ассамблеи. Ликвидация всех форм расовой дискриминации (A/RES/2646/XXV), 4 December 1970.

9 (A,RES.49)30 December 1994.

10 См.: Итоговый документ Московской конференции по человеческому измерению СБСЕ 1991 г. - Международное сотрудничество в области прав человека. Документы и материалы. Вып. 2. М.: 1993, с. 368. 
11 The European Union and the External Dimension of Human Rights Policy: From Rome to Maastricht and Beyond. Brussels. 22.11.1995. COM (95) 567 final. Para. 3.

12 Бюллетень междунаподных договоров, 1993, № 5-6, с. 4; аналогичное положение содержится также в Соглашении между Россией и Люксембургом о сотрудничестве в области культуры. - Там же, 1997, № 6, с. 31.

13 Декларация о принципах сотрудничества между Россией и Венгрией по обеспечению прав национальньх или этнических, религиозньх и языковьх менышинств 1992 г. - Там же, 1994, № 4, с. 72.

14 Договор между Россией, Белоруссией, Казахстаном и Киргизией об утлубления интеграции в экономической и гуманитарньх областях 1996 г. - Там же, 1997 , № 8 , с. 3.

15 Российская газета, 1992, 19 июня.

16 Бюллетень мехдународньх договоров, 1994, № 1.

17 X. Томушат дохазывает этот тезис, ссылаясь на многочисленные документы международных конференций, которые действительно дают основания для подобного вывода. (Ch. Tomushat. The Concluding Documents of World Order Conferences. - Theory of International Law at the Threshold of the 21st Century, p. 579.

18 International Law as a Language for International Relations. UN, 1996, p. 577.

19 CM.: L. Damrosh, G. Fox. The Right to Political Participation in International Law. - Yale J. Int'1 Law. Vol. 17 (1992), pp. 542-547, 596-597.

20 Res. 803 (83). European Yearbook. Vol. 31. 1985, p. 41.

21 Cм., например, J. Kranz. Panstwo i jego suverennosc. - Panstwo i Prawo, 1996, N. 7 , s. 19.

22 S. Sur quelques tribulations de'Etat dans la societé internationale. - RGDIP, 1993 , N. 3, p. 885.

23 См.: J. Crowford. Democracy in International Law. Cambridge, p. 3-4.

24 Хартия экономических прав и обязанностей государств 1974 г. декларирует: "Все государства юридически равны и как члены международного сообщества обладают правом участвовать полностью и эффективно в международном процессе принятия решений..."

25 1. Lukashuk. Parties to Treaties - The Right of Participation. - Recueil des Cours. Vol. 1972-I.

26Н.Ф. Касьян. Консенсус - в современных международных отношениях. M.: 1983; Institute de droit international. Annuaire. Vol. 67. T.I, Paris, 1997.

27 Г.К. Дмитриева. Принцип добросовестности в современном международном праве. - Правоведение, 1979, № 6; Р.А. Каламкарян. Принцип добросовестности в современном международном праве. М. 1991.

28 A/49/610/Add.2. 23 December 1994.

29Московский журнал международного права. 1992, № 4, с. 181.

30 ICJ. Reports 1986, p. 131.

31 См., например, Документ Московского совещания конференции по человеческому измерению СБСЕ 1991 г.

32 См., например, ч. 3 ст. 46 Конституции РФ.

33 F. Teson. Collective Humanitarian Intervention. - Michigan JIL, 1996, No. 2; R. Falk. The Complexities of Humanitarian Intervention. - Ibid.

34 В.А. Карташкин пишет: “... не топько международное сообщество в целом, но и отдельные государства в искпючительньх случаях могут прибегнуть $k$ принудительным мерам для пресечения преступных нарушений прав человека. Они по своей инициативе вправе применять для этого экономические, дипломатические и другие меры, не связанные с использованием вооруженной ситы." (В.А. Карташкин. Права человека в международном и внутригосударственном праве. M. 1995, с. 70.) 
35 U.N.: GA Res. 38/7, 2 November 1983; OAS: CP/Res. 534 (800/89), 22 December 1989.

36 ICJ. Reports 1986, p. 133.

37 U.N. Doc. S/RES/688 (1991).

38 Международная жизнь, 1995, № 3, с. 6.

39 GA Res. 47/138, 18 December 1992.

40 ILM. Vol. 31, 1992, p. 174.

41 В документе Московского совещания Конференции по человеческому измерению СБСЕ 1991 г. читаем: государства-участники “в стучае свержения или погьтки свержения демократически избранного законного правительства какого-либо государства-участника недемократическими средствами будут решитетьно поддерживать в соответствии с Уставом Организации Объединенньх Наций законные органы этого государства, стоящие на страже прав человека, де лократии и верховенства закона, признавая свои общие обязательства противодействовать любой попьтке ограничить эти основополагающие ценности" (раздел II (17.2).

42 По мнению Т. Франка принцип самоопределения, который возможно был наиболее динамичным политическим принципом двадцатого столетия, находится под угрозой пойти ко дну из-за его непоследовательности и разрушающей силы. (T. Franck. Power of Legitimacy among Nations. Oxford, 1989, p. 154, 172).

43 См.: Заявление представителя Великобритании в Комиссии 9 февраля 1988 г. - BYTL, 1988, Vol. 59, p. 442.

44 CM.: A. Cassese. The Self-Determination of Peoples. - The International Bill of Rights. N.Y. 1987, p. $86 \mathrm{ff}$; T. Franck. The Emerging Right to Democratic Governance, p. 52 ff.

45 Б. Бутрос-Гали. Речь в Институте государства и права Российской Академии Наук по случаю присуждения звания Почетного доктора права. Москва, 7 сентября. 1992 г.

46 Сr. 27 Международного пакта о гражданских и политических правах. См. также: T. Gebrehana. Duty to Negotiate. Upsala, 1978, p. 3.

47 P. Sinha. Has Self-Determination become a Principle of Intemational Law Today? - Indian JIL. Vol. 14, 1974, No. 3-4, p. 335.

48 I. Lukashuk. The Law of International Community. - International Law on the Eve of the Twenty-first Century. UN N.Y. 1997.

49 В Постановлении Конституционного Суда России от 2 февраля 1996 г. говорится, что предусмотренные процессуальным правом процедуры “должны гарантировать Ітриоритет прав и свобод человека и грақданина, не допуская предпочтения им даже самьх важньх общественньх, ведомственньгх ити личньх интересов." - Собрание законодательства Российской Федерации, 1996, № 7, ст. 701.

50 В Африканской хартии прав человека и народов 1981 г. говорится, что кахдый человек имеет обязанности в отношении общества, государства (ст. 27/1). Человек не должен, в частности, ставить под угрозу безопасность своего государства или государства проживания (ст. 29/3).

51 International Law as a Language for Intemational Relations. UN, 1996, pp. 283, 434.

52 M. Ragazzi. The Concept of International Obligations Erga Omnes. Oxford, 1997, Chapters 4-6. (erga omnes - между всеми; - лат.)

53 Южно-Африканский профессор Дж. Дюгард о своем государстве пишет: "Международное право ранее рассматривалось как угроза государству, ньпе в нем видят одну из опор новой демократии" (J. Dugard. International Law and the South African Constitution. - EJIL, 1997. No. 1, p. 77.

54 Г. Дмитриева. Становление принципа недопустимости злоупотребления правом в международном праве. - Советский ежегодник международного права, 1987. 